\title{
The Power of Social Norms for Reducing and Shifting Electricity Use
}

\begin{abstract}
$\underline{\text { Abstract }}$
New technologies are creating possibilities for making household energy consumption visible. With these technologies come opportunities for harnessing the power of social norms (viewed here as rules that are socially enforced) to affect energy consumption. But will those norms favor reductions in energy use? To answer this question, we conduct three online experiments with U.S. participants to assess individual values and normative expectations regarding household carbon emissions. We find that participants both value reducing carbon emissions and expect that others support reductions. The results have implications for nonmonetary strategies for affecting household energy consumption. In particular, they suggest that it may be possible to harness the power of social norms not only to directly affect household electricity consumption, but also to shift time of use in ways that facilitate increased incorporation of renewable sources of electricity generation, and therefore a reduced carbon footprint for the grid.
\end{abstract}

Key words: social norm, injunctive norm, normative expectation, household carbon emissions, household energy consumption

(C) 2016. This manuscript version is made available under the Elsevier user license http://www.elsevier.com/open-access/userlicense/1.0/ 


\section{The Power of Social Norms for Reducing and Shifting Energy Use}

\section{Introduction}

Household energy consumption is scrutinized, in large part because of the relationship between residential energy use and climate change. After transportation, household energy consumption is the largest contributor to greenhouse gases in the United States (U.S.) for the residential sector (Jones and Kammen, 2011; US EPA 2016), and residential emissions constitute over one-third of overall emissions in the U.S. (Vandenbergh et al., 2010). Accordingly, a large body of social science research seeks to explain household energy use (e.g., Abrahamse et al., 2005; Ehrhardt-Martinez et al., 2010; Stern and Aronson, 1984). Much of this work highlights the importance of cultural factors in shaping patterns of energy consumption (e.g., Lutzenhiser, 1992; Schot et al., 2016; Shove, 2003).

Despite evidence for the importance of cultural factors, American policy makers and utility companies responsible for serving households tend to focus on incentives directed at individuals (Lutzenhiser, 2014; Schelly, 2014). Thus, policies provide rebates for energy efficient appliances and insulation upgrades. Utilities study incentive structures for time of use, trying to identify, for example, incentives that effectively shift use from peak to off-peak times (e.g., Faruqui and Sergici, 2009). The most prominent use of non-financial approaches relies on information about how the individual compares to others in order to motivate the individual to change. (e.g., Allcott, 2011). This is a fairly thin treatment of culture, however. The research reported here uses experimental methods to provide deeper understanding of cultural influences that have implications for management of the electric grid.

There are likely many reasons for the continued utility emphasis on incentives directed at individuals and households (Lutzenhiser, 2014; Shove, 2010). To a large degree, the energy efficiency industry and the electricity delivery system are not structured in ways that facilitate recognition of the complex energy consumption dynamics described by social scientists. In the context of household 
electricity use, two features of the industry are noteworthy. First, in the U.S., energy is primarily delivered to and metered for households, not neighborhoods or communities. From the perspective of the electricity delivery system, the unitary household is the relevant unit. Second, while electricity use is metered, consumers and utilities have historically only had access to data on aggregate monthly use. Thus, much household energy consumption has been invisible (Shove, 2000; Stern et al., 2016; but see Berker, 2013). This invisibility has a number of implications: People cannot see how their household practices translate into electricity use and therefore cannot implement their energy preferences. Energy use is private, therefore normative pressures cannot operate. And, while norms regarding social practices (e.g., norms of comfort, cleanliness, and convenience) are salient to households, norms regarding energy conservation are considerably less clear. The invisibility of electricity use means that people need not (and indeed cannot) consider social norms that might directly constrain energy consumption decisions (Hechter, 1987; Lapinski and Rimal, 2005; Willer et al., 2009).

New information and communication technologies (ICT) create the potential to address these issues. In particular, new apps can be integrated into existing energy delivery systems. Apps are inherently individualistic in that they are installed on an individual's (or household's) technology (e.g., smart phone, tablet, etc.) and are used by individuals. They thus are compatible with an electricity system designed to serve households. This is particularly true for the electricity delivery system, which is in many places being upgraded with new "smart meters" that can potentially communicate with household energy apps. In addition, although apps are owned and operated by individuals, they facilitate social connection and communication. This capability means that while apps do not allow fullblown manipulations of the many elements of culture that are relevant for energy consumption, they do create the potential for engaging social norms. This is because apps provide mechanisms for increasing the visibility of electricity consumption, not only to members of the household (see Ellegård and Palm 
2011 for illustration of how visibility can lead consumers to reflect on their usage), but also to the larger community. Such visibility is essential for social norms to operate.

If new technologies are compatible with the existing energy delivery system, and can help to overcome the issue of energy invisibility in ways that facilitate the operation of social norms, then it would be possible, in principle, for policy makers and utilities to harness the power of those norms. But, if norms do not encourage people to reduce their emissions, then such efforts would be wasted. The question becomes, what norms regulate household energy consumption?

In the U.S., the answer to this question is not clear. The global warming debate is highly politicized, with prominent conservatives arguing that man-made climate change does not exist and liberals arguing that climate change is occurring and must be addressed (McCright and Dunlap 2003; 2011a; 2011b). These competing arguments are proclaimed by high-level elected officials at the state and national level, and publicized by conservative, mainstream, and liberal media. These dynamics mean that social norms regulating energy consumption and the production of carbon emissions are not obvious. Even though the vast majority of Americans are aware of the climate change issue (Shwom et al., 2015) and are concerned about it (e.g., Leiserowitz et al. 2013), they also have good reason to expect that, whatever their own personal beliefs, many others do not support efforts to reduce emissions. Given the politicized nature of the global warming debate, and the visibility of climate deniers, it is unclear just what norms prevail in the U.S.

We seek to understand whether norms encourage household reduction of carbon emissions. We focus in particular on household electricity use in the U.S. (setting aside other sources of residential emissions such as natural gas, wood, etc.). Below, we describe what we mean by "social norms." We develop three hypotheses that make predictions about what we would expect to find if U.S. social norms favor reducing carbon emissions. We describe the three online experiments that test our hypotheses and present the results. Following the presentation of our findings, we discuss the broader 
policy domain in which household energy norms are situated. In particular, we discuss carbon emissions not just in the context of household electricity use, but also in the broader context of the electricity delivery system. We explore possible implications of our findings for this broader policy arena. We conclude by noting some limitations of our research and suggesting directions for future work.

\section{Theory and Hypotheses}

For purposes of this paper, we define norms as rules or expectations about behavior that are socially enforced (Bendor and Swistak, 2001; Coleman, 1990; Horne, 2009). We want to be clear that when we talk about norms, we are not referring to the descriptive norms that have been the focus of substantial energy research and utility efforts (Allcott, 2011; Nolan et al., 2008; Schultz et al., 2007). Harnessing the power of descriptive norms involves letting people know how they are doing compared to everybody else. In essence, in that work the norm is other people's typical behavior (Cialdini, 2007; see also Bicchieri 2006). That research typically finds relatively small effects that do not depend on the visibility of the individual's actions (e.g., Abrahamse et al., 2013). In contrast, our focus is on injunctive norms. ${ }^{1}$ When such norms are in place, people expect that others will respond positively to behavior that complies with the norm and negatively to violations. Further, they enforce those norms. That is, they react more positively to those who conform than those who do not. And, to the extent they have internalized those norms so that the norms are a part of their own value system, they also express attitudes and values that are consistent with the norm. Throughout the paper, when we refer to social norms, or norms, we are talking about norms in this injunctive (rather than descriptive) sense.

\footnotetext{
${ }^{1}$ Injunctive norms have been incorporated in descriptive norms studies in minimal ways - for example, including a smiley face on the bill of households who consume less than average (Allcott, 2011; Nolan et al., 2008; Schultz et al., 2007). But, this is a fairly thin treatment of injunctive norms - which involve much more than messages from a utility company.
} 
Norms regulate household energy consumption. Many social scientists recognize that "[e]nergy use is rarely individual, but collective ... behavior is social in the sense of being oriented to sociallysanctioned goals" (Lutzenhiser, 2009:29). These socially-sanctioned goals, or norms, regulate a range of behaviors that have implications for energy consumption. Scholars have identified a number of such norms. For example, social practice theorists show that social norms in the U.S. and further afield support people maintaining a warm and well-lit home, taking frequent hot showers, and keeping food cold in the refrigerator and freezer (Lutzenhiser, 1992; Sahakian, 2014; Shove, 2003; 2010; Shove et al., 2012; Warde 2005). However, while identifying norms of comfort and convenience helps to explain energy consumption, this approach may be less useful when seeking to identify interventions that will motivate people to change their consumption. In part, this is because consumption practices are emergent, reflecting complex intersections of available technology, knowledge of how to use technologies, and social meanings attached to behaviors (Shove et al., 2012). Accordingly, while understanding the links between norms of comfort, cleanliness, and convenience helps us understand why individuals behave the way they do, it is not clear how to harness those norms to address consumption, or how to change them in ways that discourage consumption. Further, it is difficult to know how to incorporate understanding of these emergent, collective processes into an electricity delivery system built around unitary households.

Thus, at least in the short term, targeting norms regarding carbon emissions directly may be more tractable than trying to address consumption norms more broadly. This approach raises the question of whether norms regarding levels of electricity consumption and related emissions production are likely to encourage reductions in energy use. As discussed above, given the politicized nature of the global warming debate in the U.S., it is not clear what normative expectations individuals hold. On the one hand, some research suggests that norms may undermine reduction efforts. For example, some scholars report that individuals actively resist and deride efforts to reduce greenhouse gas emissions 
(Neilsen et al., 2016). On the other hand, survey data suggest that the vast majority of Americans are aware of carbon emissions and climate change (Shwom et al., 2015). Thus it is not clear whether social norms encourage household reduction in carbon emissions.

\section{$\underline{2.1 \text { Individual Values }}$}

One way to assess social norms is to consider individual attitudes and values. That is, do individuals care only about financial incentives? Or do they also hold pro-environmental values? Substantial research explores the role of price incentives in shifting and reducing electricity consumption (e.g., Buchanan et al., 2014; Faraqui and Sergici, 2009; Sweeney et al., 2013). And many policy initiatives focus on financial incentives.

But, if norms encourage reduction in emissions, and if individuals have internalized those norms, then they will express values and attitudes that support emissions reductions. Some existing research finds evidence of general pro-environmental values among North Americans. This research shows that pro-environmental behavior can be motivated by environmental concern. People with proenvironmental values make different consumption decisions than non-environmentalists - for example, they are more likely to buy hybrid cars, use less gasoline, and take public transportation (Kahn, 2007); purchase environmentally-friendly products (Kennedy et al., 2015); restore ecosystems and plant trees (Kennedy et al., 2009); and so on.

Other work focuses specifically on attitudes regarding climate change. While American attitudes have changed over time, recent surveys show that the majority (73\%) of Americans care at least somewhat about the issue of climate change (Kennedy, 2016). Further, most (72\%) of Americans support limiting carbon emissions (Wike 2016). This support varies across political ideology, however. While only $50 \%$ of Republicans support limiting greenhouse gas emissions, $82 \%$ of Democrats and $72 \%$ of Independents do. Thus the strength of concern varies across subgroups. But, there is strong public support across political parties for expanding renewable energy (Funk and Kennedy, 2016). While there 
is some variation, it appears that the majority of Americans are concerned about climate change and support reductions in fossil fuel use.

Such evidence suggests that Americans have not only price but also environmental concerns (Irwin and Baron, 2001). We apply these insights to the climate change context to predict that that people are interested in reducing both their carbon emissions and monetary costs associated with electricity use. Accordingly, we hypothesize that:

\section{H1: People will be interested in saving money and reducing carbon emissions.}

\subsection{Social Norms}

Values alone may have weak effects, however, in the absence of social support or in the presence of competing social pressures (e.g., Mackie, 1996). Further, even if people personally disagree with a norm, they may still comply with and enforce it (Willer et al., 2009). Thus, whatever people's own attitudes and values, norms can operate somewhat independently. What norms might exist in the context of household energy use?

Norms research shows that individuals who contribute to the collective good are treated more positively than those who do not (Coleman, 1990; Horne, 2009). For example, people trust and give social rewards to individuals who are altruistic, generous, or whose behavior benefits the group (Albert et al., 2007; Barclay, 2004; Fehrler and Przepiorka, 2013; Milinski et al., 2002; Wedekind and Milinski, 2000). Further, those who contribute to the collective good gain social status (Willer, 2009). In general, people tend to react negatively to those who undermine the collective good, and positively to those who contribute.

Climate change is a collective problem. This means that people who work to reduce their emissions are engaging in behavior that benefits the group. Norms theory would therefore predict that people will respond favorably to those who reduce their emissions - because such efforts contribute to 
the collective (e.g., Miliniski et al., 2006). In contrast, individual efforts to improve their own financial situation do not benefit the group. Therefore, people are unlikely to respond positively to those who simply seek to save money. While positive reactions to emissions reductions may be stronger for people who are significantly concerned about climate change, we expect that in general people will evaluate individuals who work to reduce their carbon emissions (thus contributing to the collective good) more positively than those who seek to reduce their utility bill (thereby benefitting themselves). Accordingly we hypothesize that:

\section{H2: Size of carbon emission reductions (but not utility bill reductions) will have a positive effect others' evaluations.}

Norms research also shows that individuals not only react positively to others who contribute to the collective good, they also adjust their own behavior based on how they expect others to react (Glazer and Konrad, 1996; Horne, 2009). Thus, individuals are more generous when they expect that others value generosity (Irwin and Simpson, 2013) and they behave differently when their actions are visible to others compared with when their actions are private (Horne and Irwin, 2016; Willer et al., 2009). In general, individuals use their behavior to send signals to others that will increase their status and the likelihood of receiving social rewards.

Because global warming is a collective problem, it is reasonable to expect the mechanisms that operate to sustain cooperative behavior generally to also sustain norms favoring household reductions in carbon emissions. Such norms will be effective when decisions are visible and people have reason to consider the likely reactions of others. Whatever an individual's personal beliefs about global warming, if she believes that others favor efforts to reduce emissions, the individual will change her behavior in order to make a good impression on others and encourage positive reactions. Consistent with this argument, people invest in electric Prius cars to create a good impression on others (Sexton and Sexton, 
2014). Similarly, people are more likely to purchase costly green products rather than less expensive conventional items if others will see their purchases (Berger, 2015; Griskevicius et al., 2010). And research in Europe shows that individuals contribute more money to encourage people to reduce fossil fuel use when the contribution is public rather than private (Milinski et al., 2006). Accordingly, we expect that individuals will try to present themselves to others as caring about carbon emissions:

\section{H3: People will describe themselves as more concerned about reducing carbon emission when their description is visible to others than when it is not.}

Note that it is likely that people may adjust their self-presentation depending on who exactly is

observing them. If, for example, they knew that their audience was out-of-work coal miners, they would likely not highlight their efforts to reduce their emissions or increase their use of renewables. Similarly, to the extent that their audience is their own social network, then the composition of that network would likely matter. Here we do not explore the implications of membership in different social networks or subgroups, but simply suggest that people will expect Americans in general to approve of emissions reductions.

\section{Methods}

To test our hypotheses we conducted a series of online experiments. The first two studies are vignette experiments and are purely hypothetical. The third study uses a modified trust game to create a setting in which participants believe that their decisions in the experiment have monetary consequences. Vignette experiments use short stories to manipulate experimental conditions, and then ask participants about their reactions. Vignette studies are useful for evaluating the effects of experimental manipulations on participant responses regarding values and norms (e.g. Horne et al., 
2013; Horne et al., 2015; Jasso and Opp, 1997; Opp, 2004). They thus are ideal for testing our hypotheses.

\subsection{Study 1}

Experiment 1 assessed participants' individual-level values regarding energy cost and emissions reduction. It had a between subjects design with three conditions - price, emissions, and a control condition. There were about 80 participants per condition for a total $\mathrm{N}$ of 234 .

Participants were recruited through Prolific Academic (PA) - an online hosting site serving academic researchers (Peer et al., 2017). Prolific Academic is similar to Amazon's Mechanical Turk in that it links participants to researchers and facilitates payment. Prolific Academic participants go to the PA site to look for studies they are eligible for. If they meet the eligibility requirements, they click on the study link. Once the study is completed, they are directed back to the PA site and are paid for their participation.

Participants were U.S. residents over the age of 18 . One hundred twenty-two (52\%) were women; 112 (48\%) were men. Mean age was 34.4 years (s.d. $=10.8)$. Mean education was 14.9 years $($ s.d. $=2.00)$. We measured participant ideology on a seven point scale, with higher scores indicating more conservative ideology. Participants' mean response was 3.16 (s.d. = 1.60). We also asked participants whether they tended to vote Republican or Democrat in national elections. 167 (71\%) reported voting Democrat; 67 (29\%) reported voting Republican. Thus the sample was fairly educated and liberal.

3.1.1. Experimental Manipulations. Participants read a short vignette that described a new app. In the control condition, the app was described as a tool for helping people manage and remotely control their appliances. 
Researchers are developing a new smart phone app. This app will allow you to program your appliances (like the dishwasher, washing machine, or dryer) to run when you want (even if you are not at home).

Using this app, you can run your appliances when you want.

The price and emissions conditions added onto the control condition vignette. They included the information about running appliances, but added information about either electricity costs or emissions. In the price condition, the app provided information to households about the price of electricity at different times of day. It helped households choose to run appliances at the cheapest times, thereby saving money. In the emissions condition the app provided information to households about the source of their electricity during the day - that is, when their electricity was coming from coal, natural gas, or sources with very low emissions. Households could use this information to run their appliances at times when their electricity came from green sources.

In the past, people have had no way to know [where their electricity comes from/how much their electricity costs]. The electricity that powers your home comes from a variety of sources some [(like wind turbines and solar panels) that produce very low carbon emissions and some (like coal) that produce a lot of emissions/that are very cheap and some that are very expensive]. This means that your electricity [comes from a different mix of sources/costs different amounts] at different times of day. At some times of day your electricity comes more from sources that [produce a lot of carbon emissions/are very expensive]. At other times of day your electricity comes more from sources that [produce very few carbon emissions/are very cheap]. 
Researchers are developing a new smart phone app. This app will allow you to program your appliances (like the dishwasher, washing machine or dryer) to run when you want (even if you are not home).

This app will also provide you with information about the [source/costs] of your electricity in real-time. That is for every hour of the day it will tell you how [much of your electricity comes from sources like coal and how much from sources like wind or solar/cheap or expensive your electricity is].

Using this app, you can run your appliances when you want, or at the time of day that [will produce the lowest amount of carbon emissions/is the cheapest]. This will help you reduce your household's [carbon emissions/electricity bill].

3.1.2. Measures. We then asked participants how interested they were in the app (response scale $1=$ not at all interested, $10=$ very interested). We also asked participants for the demographic information described above.

3.1.4. Results. The mean response in the control condition was 6.10 (s.d. $=2.79)$. In the price condition, the mean response was $7.98($ s.d. $=2.34)$. And in the emissions condition, the mean response was 7.45 (s.d. = 2.67). The difference between the emissions and control conditions is statistically significant $(p<.01)$. Similarly, the difference between the price and control conditions is statistically significant $(p<.0001)$. There is no statistically significant difference between the price and emissions conditions $(p=.20)$. We also checked to see if any participant characteristics - political orientation, gender, age, or education - were associated with their interest in the app. We found no statistically 
significant correlations. Further, there are no statistically significant interaction effects of the experimental conditions and demographic characteristics on responses.

Our results show that consumers are interested both in reducing their electricity costs and in reducing their carbon emissions. In our convenience sample this was the case regardless of participants' political orientation, gender, age, or education. That is, we found no differences based on participant characteristics. These results are consistent with our expectation that Americans have values that at least somewhat favor reductions in carbon emissions. Because we relied on a convenience sample, we cannot draw conclusions about Americans generally. But, that our results held across participants with different sociodemographic characteristics strengthens our expectation that similar results would be found for a broader sample. Our study shows that concerns about climate change and economic costs can be detected using this method.

\subsection{Study 2}

Study 2 tested how experiment participants evaluated a household that worked to reduce its electricity bill compared to one that worked to reduce its emissions. The study had a $2 \times 5$ design crossing household interest (reducing their bill vs emissions) by level of reduction ( $0 \%$ vs $20 \%$ vs $40 \%$ vs $60 \%$ vs $80 \%$ ). This design enables us to assess whether participants evaluated reductions in emissions more positively than reductions in a bill, and whether there was a threshold at which positive evaluations drop off. There were approximately 50 participants per condition for an $\mathrm{N}$ of 506 .

Again, participants were recruited through Prolific Academic. Mean reported ideology was 3.05 (s.d.=1.55) on a 7-point scale, with higher numbers indicating more conservative orientations. This variable is reverse coded in the statistical analyses. We asked how people tended to vote in federal presidential elections and this time gave participants an "other" option. There were 344 Democrats (68\%); 91 Republicans (18\%), and 71 other (14\%). Thus the sample was fairly liberal. The mean age was 
30.1 (s.d. = 10.3). Mean years of education was $14.9($ s.d. $=1.78)$. The sample included 314 females (62\%) and 192 males (38\%).

3.2.1. Experimental Manipulations. Participants read a vignette that described a household that was working to reduce either its utility bill or its carbon emissions:

Angie Johnson lives with her husband and two children in your neighborhood. They have lived there for a decade. Their residence is similar to others in your neighborhood in age, size, and style. Over the past year Angie has [worked to keep their household electricity use the same so that their bill/carbon emissions will stay the same/ worked to reduce their household electricity use so that their bill will go down to $\$ 80 / \$ 60 / \$ 40 / \$ 20 /$ worked to reduce their household electricity use so that their carbon emissions will go down to $\% 80 / \% 60 / \% 40 / \% 20$ of what they were].

She has been successful. Over the past year, their electricity use has [stayed the same and their bill/emissions has/ve stayed at $\$ 100 /$ gone down and their bill has gone down to $\$ 80 / \$ 60 \$ 40 / \$ 20 / g o n e$ down and their carbon emissions have gone down to $80 \% / 60 \% / 40 \% / 20 \%$ of what they were].

This approach allows us to assess whether people react more favorably to those who reduce their carbon emissions than to those who reduce their utility bill, as well as whether favorable reactions drop off at any point. More specifically, an interaction effect between the amount of reduction (0/20/40/60/80) and purpose (emissions vs bill) will provide evidence that people respond more positively to those who reduce their emissions than to those who reduce their bill. 
3.2.2. Measures. We asked participants a number of questions designed to assess their perceptions of the woman in the vignette. All of the measures had a 10-point response scale and were recoded so that higher numbers indicated more positive evaluations. We asked participants about how nice, caring, altruistic, and selfish they thought Angie was, as well as how much they would like to get to know Angie and how much they would like to have her for a neighbor.

\subsubsection{Results}

Mean responses are reported in Table 1.

[Table 1 about here]

We conducted OLS regressions to examine whether the effects of household reductions on evaluations of Angie varied depending on whether Angie was described as reducing her carbon emissions or her electricity bill. As predicted, initial analyses revealed statistically significant interaction effects between reductions and Angie's motives (to reduce her emissions or her bill). To further explore these interaction effects, we conducted analyses with disaggregated data that looked separately at the effects of reductions in the emissions and bill conditions. For clarity, we present the results using the disaggregated data (Table 2). We find that reductions have no effects in the bill condition (Models 8-14, Table 2). That is when Angie was described as reducing her electricity bill, the amount of reduction had no effect on participant evaluations. But, reductions did have effects in the carbon emissions condition (Models 1-7, Table 2). When Angie was described as reducing her carbon emissions, larger reductions generally produced more positive evaluations.

[Table 2 about here] 
While our study was not designed to test differences across sociodemographic characteristics, we conducted exploratory analyses that incorporated these characteristics. Again, we report the results of analyses conducted with disaggregated data - looking separately at the results for the condition in which Angie was working on her carbon emissions (Models 1-7, Table 3) and the condition in which she was described as seeking to reduce her electricity bill (Models 8-14, Table 3). We also simplify the manipulations to compare reactions to reductions versus no reductions (rather than incorporate all the variations in sizes of reduction). We focus first on the condition in which Angie was described as reducing her carbon emissions. Initial analyses showed no interaction effects between reductions and the political ideology of the participant; further, including the interaction term masked the effects of the experimental condition. Accordingly, we present the results without the interaction term. The main effects of Reduction suggest that both liberal and conservative participants reacted positively to Angie's efforts to reduce carbon emissions. The main effects of Liberal results show that liberal participants generally viewed Angie more positively than did conservative participants.

\section{[Table 3 about here]}

We next look at the condition in which Angie was described as wanting to reduce her electricity bill (Models 8-14). Here there were statistically significant interaction effects of participant Liberal ideology $x$ Reduction on evaluations of Angie. These positive interaction effects show that liberal participants reacted more positively to Angie's reduction in her electricity bill than did conservatives. In sum, in the condition in which Angie was described as reducing her emissions, participants from across the political spectrum viewed reductions positively. But in the condition in which Angie was described as reducing her electricity bill, liberals reacted more positively than conservatives. This result may indicate that liberals see saving money on an electricity bill as simultaneously reducing energy consumption and 
carbon emissions, and that conservatives do not make this translation. Or, it may be that conservatives are more inclined than liberals to see Angie's successes at reducing her bill as suggesting that something is wrong with their own consumption. Our study design does not allow us to specify the precise reasons for the differences between conservative and liberal participants. Future research should explore the mechanisms underlying this pattern.

In general, the results are consistent with our expectation that people give positive evaluations to those who contribute to the collective good by reducing their carbon emissions, but less so to those who seek to further their own self-interest by reducing their electricity bill. These results support the theoretical argument regarding the effects of contributions to the collective good (in this case, reducing carbon emission) on social norms. Future research should assess the generalizability of these findings with representative samples of participants.

\subsection{Study 3}

Study 3 tested whether participants used their emissions-related behavior as a signal to others. If individuals expect others to value reductions in emissions and to respond positively to those who try to reduce their emissions, then they are likely to seek to portray themselves as working toward that end. The experiment had a between subjects design with two conditions - a condition in which information about the participant was public and one in which it was private. There were approximately 50 participants per condition for a total $\mathrm{N}$ of 102.

Again, participants were recruited using Prolific Academic. All participants were over 18. Seventy participants (69\%) were women; 32 (31\%) were men (3 responses were missing). Participants were somewhat liberal. The mean response to the question about political ideology was 3.40 (s.d.=1.65) (1=extremely liberal; 7=extremely conservative). Because of the study design (described below), we did not ask participants as many demographic questions as we did in the first two experiments.

\subsubsection{Experimental Framework and Manipulations}


In this experiment, participants were told that they would be participating in a Trust Game. The purpose of telling the participants about the Trust Game was to give participants reason to care about what another person thought of them. In particular, participants knew that they might make more money if the other person trusted them.

Participants read the instructions about the Trust Game. The instructions informed them that they were assigned to the position of "Receiver". Another person would be the "Truster." The Truster was allocated four dollars. The Truster would make a decision about how many dollars to give to the Receiver. Any amount the Truster gave would be multiplied by three. The Truster could give any proportion of the four dollars in whole dollar amounts. Then the Receiver would make a decision about how many dollars to return to the Truster. Again, the Receiver could give any amount in whole dollar increments. Both the Truster and Receiver would be better off if the Truster gave dollars to the Receiver (so that the dollar value was multiplied) and the Receiver game points back to the Truster. But, if the Truster thought the Receiver would keep all the dollars, then the Truster would be less likely to give anything, resulting in the Receiver getting nothing. The instructions emphasized that it was to the participant's advantage to have the Truster trust them, so that the Truster would give them some money.

After reading the instructions, but before playing the Trust Game, participants were asked to complete a short survey. The survey provided participants with a (limited) opportunity to describe themselves.

In the visible condition, participants were told that the Truster would see their responses on the survey. After the participant completed the survey, her responses were ostensibly displayed to the Truster. In this condition, participants had reason to answer the survey questions in a way that portrayed them in the most positive light. 
In the not visible condition, participants were told that the Truster would not see their responses. After the participant completed the survey, her responses would not be displayed to the Truster. In this condition, participants had no reason to try to make themselves look good on the survey because no one was going to see their responses.

Then the Trust Game started. The Trust Game itself was irrelevant for testing our hypotheses. We were interested in what participants did before the Trust Game started - in particular, how participants answered the survey questions when the Truster could ostensibly see, or not see, their responses.

At the end of the experiment, participants were informed that the Truster was a computersimulated actor, and that the purpose of the study was to see how they responded to the survey questions. They were directed back to the PA website and paid for their participation.

\subsubsection{Measures}

Our dependent measure was participants' response to the question about how much they tried to reduce their carbon emissions ( $1=$ not at all; $10=$ very much). The response to this question provides an indicator of normative expectations. If participants expect that others support emissions reductions, then, when their answer is visible, they have reason to portray themselves as working to reduce their own emissions. If their answers is not visible, they have no reason to present themselves in a positive way. Higher responses in the visible than in the not visible condition indicates that the participant has normative expectations that others view reducing emissions as a good thing.

We also asked a few distractor questions (including participants' gender and political ideology). Because we included these questions as part of the experiment, we did not collect demographic data at the end as we did in Experiments 1 and 2.

\subsubsection{Results}


Hypothesis 3 predicts that participants would describe themselves as more committed to reducing their carbon emissions when that information was visible to the other player than when it was not. Consistent with that prediction, the mean response in the not visible condition was 5.35 (s.d. $=2.50$ ). The mean response in the visible condition was $6.34($ s.d. $=2.54)(p<.05 ; N=102)$. We replicated the study with a larger sample and found similar results. In the replication study, the mean response in the not visible condition was 5.21 (s.d.=2.65); the mean response in the visible condition was 6.16 (s.d.=2.33) $(\mathrm{p}<.01 ; \mathrm{N}=199)$. These results are consistent with the hypothesis that people would portray themselves as more concerned about their emissions when they believed that another person would see their responses. The findings suggest that people expect others to have positive views of people who try to reduce their carbon emissions. That is, people perceive norms that support emissions reductions.

We also conducted exploratory analyses with both samples that incorporated participant sociodemographic characteristics. In the smaller sample, we found that participants' characteristics had no statistically significant associations with their responses. Further, participant characteristics did not interact with the experimental conditions to affect responses. Analyses of the replication sample found some effects of participant characteristics. They showed that participant ideology both was associated with participants' responses, and moderated the effect of the visibility condition on responses. More specifically, when visibility, participant political ideology, and their interaction were included in the analysis, the visibility $(b=-2.29$; s.e. $=1.47)$ and liberal $(b=.0861$; s.e. $=.133)$ coefficients were statistically insignificant. The visibility $x$ liberal interaction coefficient $(b=.441$; s.e. $=.187)$ was statistically significant at the $p<.05$ level. ${ }^{2}$ This result suggests that liberals reacted more strongly to the

${ }^{2}$ Before conducting these exploratory analyses, we checked to see whether the experimental condition (visibility) affected participants' responses to the political ideology question. There was no statistically significant correlation. 
visibility condition than conservatives, and therefore that liberals may have stronger normative expectations regarding carbon emissions than conservatives. But given that the results of the exploratory analyses were different for the two samples, they should be interpreted with caution. Future research should assess the extent to which normative expectations vary across the political spectrum.

Our finding that participants who had to presented themselves publicly (rather than privately) reported more efforts to reduce their emissions suggests that participants expected such information to produce positive reactions. This result is consistent with the theoretical argument. The finding that participants expected others to respond positively to reductions in emissions supports our theory that norms encourage people to contribute to the collective good (in this case, by reducing their carbon emissions). Future research should assess the generalizability of these findings.

\section{Policy Context}

Utility companies and policy-makers are under increasing pressure to address global warming. Utility company practices have implications for carbon emissions in at least two ways. First, because demand for electricity is higher at some times of day than at others, utilities need to maintain generation plants that can be quickly brought on line to meet peak load. These plants typically rely on fossil fuels. Accordingly, shifting customer demand away from peak use times could reduce the need to maintain these polluting plants, thus decreasing emissions. Second, new policies mandate increases in the amount of electricity that is generated using renewable sources rather than fossil fuels. Responding to such policy mandates is a challenge for utility companies (e.g., Bakke 2016). Because renewable sources of electricity are intermittent and unpredictable, utility companies that incorporate renewables into their energy mix have to figure out what to do when the wind stops blowing (or blows too much), or the sun stops shining (or shines too much). These two factors, in conjunction with pressures to keep 
costs low, are increasing utility interest in "demand response" - management of the timing of household electricity consumption.

Even as policies and utility practices tend to focus on financial incentives to shift time of use, research on household energy consumption identifies a range of factors that contribute to level of electricity use. As described above, social practice researchers elucidate the complexity of household energy-related practices. Such research embeds energy decisions in cultural contexts that include materials, norms, habits, and skills.

These two objectives (shifting versus reducing use) have typically been pursued separately. As a result, there is little coordination between strategies that rely on cultural factors to reduce energy use and efforts to run the grid that focus on shifting time of use. In other words, household reduction does not help manage load, and managing load has the potential to, but does not necessarily, reduce carbon emissions.

New technologies increase the tools available for coordinating these disparate efforts. Further, in principle, they allow for engaging consumers more actively in grid governance. Consider, for example, a model in which consumers make real-time (automated) choices. If consumers prefer clean energy, then when the sun goes behind a cloud, they will accept their dryer stopping for a few minutes until the cloud goes away, or their air conditioner setting shifting by a few degrees. In the aggregate, such decisions will produce greater demand on the system when electricity is generated by a higher proportion of clean (e.g., solar and wind) rather than dirty (e.g., coal) sources. While individual preferences could produce some shift, our results suggest that normative pressures have the potential to magnify these effects. Notably, in this vision, social norms produce reductions in emissions through two pathways - reducing the household's absolute level of use and shifting time of use to periods when more electricity generated from renewable sources is in the system. Social norms both encourage households to reduce their electricity use, and also create bottom-up pressure for a cleaner grid. If 
consumers knew, for example, that during the day, their energy mix was $30 \%$ renewables, and at night was $100 \%$ coal, then they might well run their dishwasher in the morning when the sun is up, instead of after they go to bed. These shifts in demand would provide utilities and state regulators with information about what consumers want and are willing to pay for. Such information could provide the basis for increasing investments in renewables relative to coal, even if such investments are more costly and difficult to justify given current regulatory mandates to keep rates low.

Such integration of consumers would require significant technological development. Before making such investments, it makes sense to examine whether customers are best motivated by financial incentives. If consumers care only about money, then demand response and dynamic pricing schemes based solely on price may be the most effective tool for shifting consumer behavior, and there is little hope for reducing emissions until doing so is cost effective for households. Policy makers should look no further than pricing schemes. But if consumers also care about the environment, then harnessing the power of social norms in ways that coordinate with grid management could reduce emissions. For this reason, it is worth understanding cultural factors underlying household energy consumption. The present paper represents an initial step in this direction - assessing several aspects of norms regulating household electricity consumption.

\section{Conclusion and Policy Implications}

New technologies facilitate making consumer behavior visible and thereby harness the power of social norms to affect energy-related behavior. Further these technologies can coordinate consumer decisions with grid management in ways that could impact the composition of the energy generation mix on which utility companies rely. But this can only happen if social norms and individual values support reductions in emissions. To begin to assess this issue, we use three online experiments to measure values and norms regarding reduction in household carbon emissions among our U.S. study 
participants. We find that participants value both money and the environment. But, social norms operate primarily to encourage reductions in carbon emissions (rather than utility bills). More specifically, our findings suggest that participants are interested in reducing both their carbon emissions and their electricity related costs. Further, the results show that people have more favorable impressions of others who care about reducing emissions as compared to those who reduce their electricity bill, and that they portray themselves to others as caring about reducing emissions. These results provide evidence that both individual values and social norms support reductions in carbon emissions.

\section{$\underline{5.1 \text { Limitations and Future Research }}$}

One limitation of our research is that the study samples are not representative. Our exploratory analyses find some differences associated with participant political ideology. Existing research similarly shows that, particularly in the U.S., those with a liberal ideology are more likely to express concern about the environment (Leiserowitz et al., 2013; McCright et al., 2014). However, we cannot generalize our findings regarding the effects of ideology to the broader U.S. population. Future research should identify norms among different subgroups, and should be conducted with representative samples in order to assess social norms regarding carbon emissions across the political spectrum. For example, survey research with nationally representative samples could examine the generalizability of our findings, and provide evidence of the distribution of the norms we identify here. Qualitative studies could more fully describe the cultural processes at work in households, exploring the dynamics of individual values, social practices and norms, and people's sense of personal responsibility and efficacy to reduce emissions.

Another limitation of our study is that it relies on self-reports; participants did not actually engage in emissions-reducing behaviors. Our results therefore say little about the trade-off between the strength of the individual's desire to look good to others and the real difficulties of changing energy 
consumption behaviors. Experiment 3 involved real potential consequences - potentially less money at the end of the experiment. But the amounts of money involved were small. To address these limitations, future research should incorporate the ideas discussed here into an app that households actually use in order to help households manage their energy consumption and test the effectiveness of social norms features.

Finally, our study focuses specifically on household electricity consumption in the context of the electricity delivery system. It does not address other forms of household energy consumption such as natural gas and wood for cooking and heating, or fuel for transportation. These other forms of consumption may well differ from electricity in terms of their amenability to change and connections to household practices, their cultural meanings, and the perceived needs of the household.

\section{$\underline{5.1 \text { Policy Implications }}$}

Our results suggest that policy makers and utility companies interested in motivating consumers to reduce their electricity consumption have potential tools other than price. Such alternatives are particularly important in regions where electricity prices are low and financial incentives relatively small. While not examining the full range of relevant cultural factors and processes, our work suggests that social norms favor reducing carbon emissions. The implication is that people may use reducing carbon emissions as a social signal. If so, then finding ways to make electricity consumption and carbon emissions visible ought to create social pressure on individuals to reduce their consumption. Of course one should not make people's electricity use public against their will. And it is likely that people who are inclined to want to reduce their emissions are most likely to make their consumption decisions public. But, such efforts, even if not universal, can help to further shift social norms in the direction of reducing emissions.

Our results also suggest that whereas demand response programs that rely on price incentives work primarily through people's values (regarding money), programs that focus on reducing carbon 
emissions have the potential to harness not just individual values but also social norms. New technologies create possibilities for making energy-related behavior visible in ways that were not possible in the past. It is worth noting that simply developing new technology does not necessarily create the knowledge needed to effectively use the technology (see, e.g., Thomsen et al., 2013 on passive and zero energy buildings). Nonetheless, new technologies hold promise. Our findings have implications not only for electricity consumption, but also for other emissions-related behaviors such as green purchasing and household investments in solar energy. For example, because rooftop solar is more visibly connected to the household than community solar, social norms are likely to have more influence on decisions to invest in the former than the latter.

Of course, simply incorporating norms into intervention efforts does little to address the broader context within which energy consumption occurs. It does nothing, for example, to address a housing stock that is poorly insulated and sited without attention to solar gain, appliances with phantom loads, competing normative pressures to increase energy consumption, inequitable access to skills and know-how that support energy conservation, or perverse incentives that discourage investments in renewable energy. But, harnessing the power of social norms to affect household emissions can complement other efforts for institutional-level change.

\section{$\underline{5.3 \text { Conclusion }}$}

In sum, the research reported here provides insight into values and norms regarding household carbon emissions. The results suggest that social norms are an untapped tool that may be useful for encouraging households to reduce and/or shift their electricity consumption. Attention to social norms offers an avenue for bridging current individualistic policy and cultural approaches to understanding household energy consumption. Further, integrating the norms-based approach we describe into new ICT has implications not only for households, but also for the electricity delivery system. 


\section{References}

Abrahamse, W., Steg, L., Vlek, C., Rothengatter, T., 2005. A review of intervention studies aimed at household energy conservation. J. Environ. Psychol. 25, 273-291.

Abrahamse, W., Steg, L., 2013. Social influence approaches to encourage resource conservation: A metaanalysis. Glob. Environ. Change 23(6), 1773-1785.

Albert M., Güth, W., Kirchler, E., Maciejovsky, B., 2007. Are we nice(r) to nice(r) people? An experimental analysis. Exp. Econ. 10, 53-69.

Allcott, H., 2011. Social norms and energy conservation. J. Pub. Econ 95, 1082-95.

Alliance to Save Energy. 2013. Top 10 energy efficiency smartphone apps. March, 18, 2013.

http://www.ase.org/resources/top-10-energy-efficiency-smartphone-apps Retrieved October 5, 2016.

Bakke, Gretchen. 2016. The Grid: The Fraying Wires between Americans and Our Energy Future. NY: Bloomsbury.

Barclay, P., 2004. Trustworthiness and competitive altruism can also solve the 'Tragedy of the Commons.'" Evol. and Hum. Behav. 25, 209-220.

Bendor, J., Swistak, P., 2001. The evolution of norms. Am. J. Sociol. 106(6), 1493-1545. 
Berger, J., 2015. Is willingness to pay for environmentally friendly products a signal for trustworthiness?

Evidence from laboratory experiments. Social Norms Conference. Ascona, Switzerland. May 2015.

Berker, T. 2013. In the morning I just need a long, hot shower: A sociological exploration of energy sensibilities in Norwegian bathrooms. Sustainability: Science, Practice, and Policy.

http://sspp.proquest.com Retrieved November 1, 2016.

Bicchieri, C., 2006. The Grammar of Society. Cambridge University Press, Cambridge.

Buchanan, K., Russo, R., \& Anderson, B. (2014). Feeding back about eco-feedback: How do consumers use and respond to energy monitors?. Energy Policy, 73, 138-146.

Cialdini, R.B., 2007. Descriptive norms as underappreciated sources of social control." Psychom. 72(2), 263-268.

Coleman, J.A., 1990. Foundations of Social Theory. Belknap Press, Cambridge.

Ellegård, K. and Palm, J., 2011. Visualizing energy consumption activities as a tool for making everyday life more sustainable. Applied Energy, 88(5), 1920-1926.

Ehrhardt-Martinez, K., Donnelly, K.A., Laitner, J.A., 2010. Advanced metering initiatives and residential feedback programs: A meta-review for household electricity-saving opportunities." Report Number E105. American Council for an Energy-Efficient Economy. 
Faruqui, A., Sergici, S., 2009. Household Response to Dynamic Pricing of Electricity - A Survey of the Experimental Evidence. The Brattle Group.

Fehrler, S., Przepiorka, W., 2013. Charitable giving as a sign of trustworthiness: Disentangling the signaling benefits of altruistic acts. Evol. and Hum. Behav. 34, 139-145.

Funk, C., Kennedy, B., 2016. The politics of climate. Pew Research Center. http://www.pewinternet.org/2016/10/04/the-politics-of-climate/ Retrieved November 1, 2016.

Glazer, A., Konrad, K.A., 1996. A signaling explanation for charity. Am. Econ. Rev. 86(4), 1019-1028.

Griskevicius, V., Tybur, J.M., Van den Bergh, B., 2010. Going green to be seen: Status, reputation, and conspicuous conservation" J. Personal. \& Soc. Psychol. 98(3), 392-404.

Hechter, M. 1987. Principles of Group Solidarity. University of California Press, Berkeley.

Horne, C. 2009. The Rewards of Punishment. Stanford University Press, Stanford.

Horne, C., Darras, B., Bean, E., Srivastava, A., Frickel, S. 2015. Privacy, technology, and norms: The case of smart meters." Soc. Sc. Res. 51, 64-76.

Horne, C., Dodoo, F.N-A., Dodoo, N.D., 2013. The shadow of indebtedness: Bridewealth and norms constraining female reproductive autonomy. Am. Sociol. Rev. 78(3), 503-520. 
Horne, C., Irwin, K. 2016. Metanorms and antisocial punishment. Social Influ. 11(1), 7-21.

IFTT (If This Then That). 2016. https://ifttt.com/recipes/search?q=energy Retrieved April 18, 2016.

Irwin, J.R., Baron, J., 2001. Response mode effects and moral values. Organ. Beh. \& Human Decis.

Process. 84(2), 177-197.

Irwin, K., Simpson, B., 2013. Do descriptive norms solve social dilemmas? Conformity and contributions in collective action groups. Soc. Forces 91(3), 1057-1084.

Jasso, G., Opp, K-D., 1997. Probing the character of norms: A factorial survey analysis of the norms of political action. Am. Sociol. Rev. 62(6), 947-964.

Jones, C. M., Kammen, D. M., 2011. Quantifying carbon footprint reduction opportunities for US households and communities. Environ. Sc. \& Technol. 45(9), 4088-4095.

Kahn, M.E., 2007. Do greens drive hummers or hybrids? Environmental ideology as a determinant of consumer choice. J. Environ. Econ. \& Management 54(2), 129-145.

Kennedy, B., 2016. Clinton, Trump supporters worlds apart on views of climate change and its scientists. Pew Research Center. http://www.pewresearch.org/fact-tank/2016/10/10/clinton-trump-supportersworlds-apart-on-views-of-climate-change-and-its-scientists/ Retrieved November 2, 2016. 
Kennedy, E.H., Krahn, H., Krogman, N. T., 2015. Are we counting what counts? A closer look at environmental concern, pro-environmental behaviour, and carbon footprint. Local Envir., 20(2), 220236.

Kennedy, E.H., Beckley, T. M., McFarlane, B. L., Nadeau, S., 2009. Rural-urban differences in environmental concern in Canada. Rural Sociol., 74(3), 309-329.

Lapinski, M.K., Rimal, R.N., 2005. An explication of social norms. Commun. Theory 15, 127-147.

Leiserowitz, A. A., Maibach, E. W., Roser-Renouf, C., Smith, N., Dawson, E., 2013. Climategate, public opinion, and the loss of trust. Am. Behav. Sci. 57(6), 818-837.

Lutzenhiser, L., 1992. A cultural model of household energy consumption. Energy 17(1), 47-60.

Lutzenhiser, L., 2009. Behavioral Assumptions Underlying California Residential Sector Energy Efficiency Programs. University of California CIEE.

http://www1.eere.energy.gov/buildings/betterbuildings/neighborhoods/pdfs/ba_ee_res_wp.pdf Retrieved November 7, 2016.

Lutzenhiser, L., 2014. Through the energy efficiency looking glass. Energy Research \& Soc. Sci. 1, 141151.

Mackie, G. 1996. Ending footbinding and infibulation: A convention account. Am. Sociol. Rev. 61, 9991017. 
McCright, A.M., Xiao, C., Dunlap, R.E., 2014. Political polarization on support for government spending on environmental protection in the USA, 1974-2012. Soc. Sci. Res. 48, 251-260.

McCright, A.M. and Dunlap, R.E., 2003. Defeating Kyoto: The conservative movement's impact on US climate change policy. Social Problems, 50(3), 348-373.

McCright, A. M., \& Dunlap, R. E. 2011a. The politicization of climate change and polarization in the American public's views of global warming, 2001-2010. Sociol. Quarterly, 52(2), 155-194.

McCright, A.M., Dunlap, R.E., 2011b. Cool dudes: The denial of climate change among conservative white males in the United States." Glob. Environ. Change 21, 1163-1172.

Milinski, M., Semmann, D., Krambeck, H.J., 2002. Donors to charity gain in both indirect reciprocity and political reputation. Proc. R. Soc. London B 269, 573-377.

Miliniski, M., Semmann, D., Krambeck, H.J., Marotzke, J. 2006. Stabilizing the earth's climate is not a losing game: Supporting evidence from public goods experiments." PNAS 103(11), 3994-3998.

Nielsen, K. R., Reisch, L. A., \& Thøgersen, J. 2016. Sustainable user innovation from a policy perspective: A systematic literature review. J. of Cleaner Production, 133, 65-77.

Nolan, J., Schultz, W., Cialdini, R., Goldstein, N., Griskevicius, V. 2008. Normative influence is underdetected. Personal. \& Soc. Psychol. Bull. 34, 913-923. 
Opp, K.-D., 2004. 'What is is always becoming what ought to be.' How political action generates a participation norm. European Sociol. Rev. 20(1), 13-29.

Peer, E., Brandimarte, L., Samat, S., Acquisti, S. 2017. Beyond the Turk: Alternative platforms for crowdsourcing behavioral research. J. Exp. Soc. Psychol. 70, 153-163.

Sahakian, M. 2014. Keeping Cool in Southeast Asia: Energy Consumption and Urban Air-Conditioning. Palgrave Macmillan UK, London.

Schelly, C. 2014. Implementing renewable energy portfolio standards: The good, the bad, and the ugly in a two state comparison. Energy Policy, 67, 543-551.

Schot, J, Kanger, L., Verbong, G. 2016. The roles of users in shaping transitions to new energy systems. Nat. Energy 1, 1-7.

Schultz, W., Nolan, J., Cialdini, R., Goldstein, N., Griskevicius, V., 2007. The constructive, destructive, and reconstructive power of social norms. Psychol. Sc. 18, 429-434.

Sexton, S.E., Sexton, A.L., 2014. Conspicuous conservation: The Prius halo and willingness to pay for environmental bona fides. J. Environ. Econ. \& Manag. 67, 303-317.

Shove, E., 2000. Revealing the invisible: Sociology, energy and the environment. Int. Yearb. Environ. \& Resour. Econ. 2000/2001, 261. 
Shove, E., 2003. Comfort, Cleanliness and Convenience: The Social Organization of Normality. Berg, Oxford.

Shove, E., 2010. Beyond the ABC: climate change policy and theories of social change. Environ. \& Planning A, 42(6), 1273-1285.

Shove, E., Pantzar, M. and Watson, M., 2012. The Dynamics of Social Practice: Everyday Life and How It Changes. Sage Publications, New York.

Shwom, R. L., McCright, A. M., Marquart-Pyatt, S. T., Hamilton, L. C., 2015. Public opinion on climate change, in: Dunlap, R.E., Brulle, R.J. (Eds.), Climate Change and Society: Sociological Perspectives, New York: Oxford University Press, New York, pp. 269-299.

Stern, P.C., Aronson, E., (Eds.) 1984. Energy Use: The Human Dimension. W.H. Freeman and Company, New York.

Stern, P.C., Janda, K.B., Brown, M.A., Steg, L., Vine, E.L., Lutzenhiser, L. 2016. Opportunities and insights for reducing fossil fuel consumption by households and organization." Nat. Energy 1, 1-6.

Sweeney, J. C., Kresling, J., Webb, D., Soutar, G. N., \& Mazzarol, T. (2013). Energy saving behaviours: Development of a practice-based model. Energy Policy 61, 371-381. 
Thomsen, J., Berker, T., Lappegard Hauge, Å., Denizou, K., Wågø, S. and Jerk $\varnothing$, S., 2013. The interaction between building and users in passive and zero-energy housing and offices: the role of interfaces, knowledge and user commitment. Smart \& Sustainable Built Environ. 2(1), 43-59.

United States Environmental Protection Agency (US EPA). 2016. Inventory of U.S. Greenhouse Gas Emissions and Sinks: 1990-2014. U.S. Environmental Protection Agency, April 15, 2016. Washington, DC: USA. Accessed from: https://www.epa.gov/ghgemissions/us-greenhouse-gas-inventory-report-19902014 . Accessed on November 1, 2016.

Vandenbergh, M.P., Stern, P.C., Gardner, G.T., Dietz, T., Gilligan, J.M. 2010. Implementing the behavioral wedge: Designing and adopting effective carbon emissions reduction programs. Environ. Law Report. 40, 10547-10554.

Warde, A., 2005. Consumption and theories of practice. J. Consum. Cult., 5(2), 131-153.

Wedekind, C., Miliniski, M., 2000. Cooperation through image scoring in humans. Sci. 288:850-852.

Wike, R., 2016. What the world thinks about climate change in 7 charts. Pew Research Center.

http://www.pewresearch.org/fact-tank/2016/04/18/what-the-world-thinks-about-climate-change-in-7charts/ Recovered October 31, 2016.

Willer, R., 2009. The status solution to the collective action problem. Am. Sociol. Rev. 74, 23-43.

Willer, R., Kuwabara, K., Macy, M., 2009. The false enforcement of unpopular norms. Am. J. Sociol. 115(2), 451-490. 
Table 1. Mean Evaluations across Experimental Conditions

\begin{tabular}{|c|c|c|c|}
\hline & & $\begin{array}{l}\text { Emissions } \\
\text { Reduction } \\
\text { Mean (s.d.) N }\end{array}$ & $\begin{array}{l}\text { Bill } \\
\text { Reduction } \\
\text { Mean (s.d.) N }\end{array}$ \\
\hline $\begin{array}{l}\text { Amount of } \quad 0 \% \\
\text { Reduction }\end{array}$ & $\begin{array}{l}\text { Altruistic } \\
\text { Nice } \\
\text { Care } \\
\text { Trust } \\
\text { Neighbor } \\
\text { Know } \\
\text { Unselfish }\end{array}$ & $\begin{array}{llll}6.35 & (2.12) & 51 \\
6.75 & (1.49) & 51 \\
6.69 & (1.33) & 51 \\
5.82 & (1.34) & 51 \\
7.06 & (1.86) & 51 \\
6.10 & (1.82) & 51 \\
7.39 & (1.84) & 51\end{array}$ & $\begin{array}{lll}6.38 & (1.75) & 50 \\
6.80 & (1.63) & 51 \\
6.59 & (1.28) & 51 \\
6.47 & (2.06) & 51 \\
6.88 & (1.95) & 51 \\
6.08 & (1.85) & 51 \\
6.78 & (1.70) & 51\end{array}$ \\
\hline $20 \%$ & $\begin{array}{l}\text { Altruistic } \\
\text { Nice } \\
\text { Care } \\
\text { Trust } \\
\text { Neighbor } \\
\text { Know } \\
\text { Unselfish }\end{array}$ & $\begin{array}{llll}7.92 & (1.73) & 51 \\
7.65 & (1.49) & 51 \\
7.57 & (1.10) & 51 \\
6.59 & (1.76) & 51 \\
7.84 & (1.78) & 51 \\
7.00 & (1.87) & 51 \\
7.80 & (2.20) & 51\end{array}$ & $\begin{array}{lll}6.60 & (1.39) & 52 \\
7.00 & (1.25) & 52 \\
6.90 & (1.05) & 52 \\
6.06 & (1.54) & 52 \\
7.33(1.42) & 52 \\
6.37(1.44) & 52 \\
7.21(1.30) & 52\end{array}$ \\
\hline $40 \%$ & $\begin{array}{l}\text { Altruistic } \\
\text { Nice } \\
\text { Care } \\
\text { Trust } \\
\text { Neighbor } \\
\text { Know } \\
\text { Unselfish }\end{array}$ & $\begin{array}{lll}7.46 & (1.90) & 48 \\
7.44 & (1.75) & 48 \\
7.52 & (1.09) & 48 \\
6.79 & (2.21) & 47 \\
8.00 & (1.80) & 48 \\
6.90 & (2.18) & 47 \\
8.19 & (1.48) & 48 \\
\end{array}$ & $\begin{array}{lll}6.56 & (1.88) & 50 \\
7.10 & (1.35) & 51 \\
6.90 & (1.20) & 51 \\
6.37 & (1.79) & 51 \\
7.59 & (1.49) & 51 \\
6.49 & (1.71) & 51 \\
7.16 & (1.91) & 51 \\
\end{array}$ \\
\hline $60 \%$ & $\begin{array}{l}\text { Altruistic } \\
\text { Nice } \\
\text { Care } \\
\text { Trust } \\
\text { Neighbor } \\
\text { Know } \\
\text { Unselfish }\end{array}$ & $\begin{array}{lll}7.45 & (1.53) & 51 \\
7.37 & (1.36) & 51 \\
7.49 & (1.08) & 51 \\
6.33 & (1.52) & 51 \\
7.51 & (1.59) & 51 \\
6.43 & (1.77) & 51 \\
7.67 & (1.65) & 51 \\
\end{array}$ & $\begin{array}{lll}6.63 & (1.67) & 51 \\
6.90 & (1.58) & 52 \\
6.85 & (1.24) & 52 \\
6.33 & (1.64) & 52 \\
7.08 & (1.72) & 52 \\
6.62 & (1.92) & 52 \\
6.85 & (1.89) & 52\end{array}$ \\
\hline $80 \%$ & $\begin{array}{l}\text { Altruistic } \\
\text { Nice } \\
\text { Care } \\
\text { Trust } \\
\text { Neighbor } \\
\text { Know } \\
\text { Unselfish }\end{array}$ & $\begin{array}{lll}7.56 & (1.54) & 48 \\
7.53 & (1.62) & 49 \\
7.45 & (1.34) & 49 \\
6.75 & (1.68) & 48 \\
7.65 & (1.63) & 49 \\
6.73 & (2.09) & 49 \\
7.86 & (1.72) & 49\end{array}$ & $\begin{array}{lll}6.57 & (1.98) & 49 \\
6.86 & (1.35) & 49 \\
6.78 & (1.23) & 49 \\
6.65 & (1.56) & 49 \\
7.27 & (1.54) & 49 \\
6.67 & (1.66) & 49 \\
7.20 & (1.51) & 49\end{array}$ \\
\hline
\end{tabular}


Table 2. OLS Regression Showing Effects of Reductions on Evaluations in the Emissions and Bill Conditions

\begin{tabular}{|c|c|c|c|c|c|c|c|}
\hline & \multicolumn{7}{|c|}{ Reduce Emissions Condition } \\
\hline & $\begin{array}{l}\text { Model } 1 \\
\text { Altruistic } \\
\text { b (s.e.) }\end{array}$ & $\begin{array}{l}\text { Model } 2 \\
\text { Nice } \\
\text { b (s.e.) }\end{array}$ & $\begin{array}{l}\text { Model } 3 \\
\text { Care } \\
\text { b (s.e.) }\end{array}$ & $\begin{array}{l}\text { Model } 4 \\
\text { Trust } \\
\text { b (s.e.) }\end{array}$ & $\begin{array}{l}\text { Model } 5 \\
\text { Neighbor } \\
\text { b (s.e.) }\end{array}$ & $\begin{array}{l}\text { Model } 6 \\
\text { Know } \\
\text { b (s.e.) }\end{array}$ & $\begin{array}{l}\text { Model } 7 \\
\text { Unselfish } \\
\text { b (s.e.) }\end{array}$ \\
\hline Intercept & $\begin{array}{l}6.35^{* * *} \\
(.249)\end{array}$ & $\begin{array}{l}6.75^{* * *} \\
(.216)\end{array}$ & $\begin{array}{l}6.69 * * * \\
(.167)\end{array}$ & $\begin{array}{l}5.82^{* * *} \\
(.240)\end{array}$ & $\begin{array}{l}7.06^{* * *} \\
(.243)\end{array}$ & $\begin{array}{l}6.10 * * * \\
(.273)\end{array}$ & $\begin{array}{l}7.39 * * * \\
(.252)\end{array}$ \\
\hline $\begin{array}{l}20 \% \\
\text { Emissions } \\
\text { Reduction }\end{array}$ & $\begin{array}{l}1.57^{* * *} \\
(.353)\end{array}$ & $\begin{array}{l}.902 * * \\
(.306)\end{array}$ & $\begin{array}{l}.882^{* * *} \\
(.237)\end{array}$ & $\begin{array}{l}.765^{*} \\
(.340)\end{array}$ & $\begin{array}{l}.784^{*} \\
(.344)\end{array}$ & $\begin{array}{l}.902 * \\
(.386)\end{array}$ & $\begin{array}{l}.412 \\
(.356)\end{array}$ \\
\hline $\begin{array}{l}40 \% \\
\text { Emissions } \\
\text { Reduction }\end{array}$ & $\begin{array}{l}1.11^{* *} \\
(.358)\end{array}$ & $\begin{array}{l}.692 * \\
(.311)\end{array}$ & $\begin{array}{l}835 * * * \\
(.240)\end{array}$ & $\begin{array}{l}.964^{* *} \\
(.347)\end{array}$ & $\begin{array}{l}.941 * * \\
(.349)\end{array}$ & $\begin{array}{l}.796 * \\
(.394)\end{array}$ & $\begin{array}{l}.795^{*} \\
(.362)\end{array}$ \\
\hline $\begin{array}{l}60 \% \\
\text { Emissions } \\
\text { Reduction }\end{array}$ & $\begin{array}{l}1.10 * * \\
(.353)\end{array}$ & $\begin{array}{l}.627^{*} \\
(.306)\end{array}$ & $\begin{array}{l}.804 * * * \\
(.237)\end{array}$ & $\begin{array}{l}.510 \\
(.340)\end{array}$ & $\begin{array}{l}.451 \\
(.344)\end{array}$ & $\begin{array}{l}.333 \\
(.386)\end{array}$ & $\begin{array}{l}.275 \\
(.356)\end{array}$ \\
\hline $\begin{array}{l}80 \% \\
\text { Emissions } \\
\text { Reduction }\end{array}$ & $\begin{array}{l}1.21^{* * *} \\
(.358)\end{array}$ & $\begin{array}{l}.786 * \\
(.309)\end{array}$ & $\begin{array}{l}.763^{* *} \\
(.239)\end{array}$ & $\begin{array}{l}.926 * * \\
(.345)\end{array}$ & $\begin{array}{l}.594+ \\
(.347)\end{array}$ & $\begin{array}{l}.637+ \\
(.389)\end{array}$ & $\begin{array}{l}.465 \\
(.360)\end{array}$ \\
\hline R-Square & .08 & .04 & .07 & .04 & .03 & .03 & .02 \\
\hline $\mathrm{N}$ & 249 & 250 & 250 & 248 & 250 & 249 & 250 \\
\hline
\end{tabular}

The omitted category is $0 \%$ Emissions Reduction.

Reduce Bill Condition

\begin{tabular}{|c|c|c|c|c|c|c|c|}
\hline & $\begin{array}{l}\text { Model } 8 \\
\text { Altruistic } \\
\text { b (s.e.) }\end{array}$ & $\begin{array}{l}\text { Model } 9 \\
\text { Nice } \\
\text { b (s.e.) }\end{array}$ & $\begin{array}{l}\text { Model } 10 \\
\text { Care } \\
\text { b (s.e.) }\end{array}$ & $\begin{array}{l}\text { Model } 11 \\
\text { Trust } \\
\text { b (s.e.) }\end{array}$ & $\begin{array}{l}\text { Model } 12 \\
\text { Neighbor } \\
\text { b (s.e.) }\end{array}$ & $\begin{array}{l}\text { Model } 13 \\
\text { Know } \\
\text { b (s.e.) }\end{array}$ & $\begin{array}{l}\text { Model } 14 \\
\text { Unselfish } \\
\text { b (s.e.) }\end{array}$ \\
\hline Intercept & $\begin{array}{l}6.38^{* * * *} \\
(.246)\end{array}$ & $\begin{array}{l}6.80 * * * * \\
(.201)\end{array}$ & $\begin{array}{l}6.59 * * * * \\
(.169)\end{array}$ & $\begin{array}{l}6.47^{* * * *} \\
(.242)\end{array}$ & $\begin{array}{l}6.88^{* * * *} \\
(.229)\end{array}$ & $\begin{array}{l}6.08 * * * * \\
(.242)\end{array}$ & $\begin{array}{l}6.78^{* * * *} \\
(.235)\end{array}$ \\
\hline $20 \%$ Bill & .216 & .196 & .316 & -.413 & .445 & .287 & .427 \\
\hline Reduction & $(.345)$ & $(.283)$ & $(.237)$ & $(.341)$ & $(.322)$ & $(.340)$ & $(.331)$ \\
\hline $40 \%$ Bill & .180 & .294 & .314 & -.0980 & $.706^{*}$ & .412 & .373 \\
\hline Reduction & $(.348)$ & $(.285)$ & $(.239)$ & $(.343)$ & $(.324)$ & $(.342)$ & $(.333)$ \\
\hline $60 \%$ Bill & .247 & .100 & .258 & -.144 & .195 & .537 & .0618 \\
\hline Reduction & $(.346)$ & $(.283)$ & $(.237)$ & $(.341)$ & $(.322)$ & $(.340)$ & $(.331)$ \\
\hline $80 \%$ Bill & .191 & .0532 & .187 & .182 & .383 & $.595+$ & .420 \\
\hline Reduction & $(.350)$ & $(.288)$ & $(.241)$ & $(.346)$ & $(.327)$ & $(.345)$ & $(.336)$ \\
\hline R-Square & .00 & .01 & .01 & .01 & .02 & .01 & .01 \\
\hline $\mathrm{N}$ & 252 & 255 & 255 & 255 & 255 & 255 & 255 \\
\hline
\end{tabular}

The omitted category is $0 \%$ Bill Reduction.

$+p<.1 ;{ }^{*} p<.05 ; * * p<.01 ; * * * p<.001$ (two-tailed tests) 
Table 3. OLS Regressions with Disaggregated Data Incorporating the Experimental Conditions and Participant Ideology

Reduce Emissions Condition

\begin{tabular}{|c|c|c|c|c|c|c|c|}
\hline & $\begin{array}{l}\text { Model } 1 \\
\text { Altruistic } \\
\text { b (s.e.) }\end{array}$ & $\begin{array}{l}\text { Model } 2 \\
\text { Nice } \\
\text { b (s.e.) }\end{array}$ & $\begin{array}{l}\text { Model } 3 \\
\text { Care } \\
\text { b (s.e.) }\end{array}$ & $\begin{array}{l}\text { Model } 4 \\
\text { Trust } \\
\text { b (s.e.) }\end{array}$ & $\begin{array}{l}\text { Model } 5 \\
\text { Neighbor } \\
\text { b (s.e.) }\end{array}$ & $\begin{array}{l}\text { Model } 6 \\
\text { Know } \\
\text { b (s.e.) }\end{array}$ & $\begin{array}{l}\text { Model } 7 \\
\text { Unselfish } \\
\text { b (s.e.) }\end{array}$ \\
\hline Intercept & $\begin{array}{l}6.22^{* * * *} \\
(.419)\end{array}$ & $\begin{array}{l}6.39 * * * * \\
(.356)\end{array}$ & $\begin{array}{l}6.48^{* * * *} \\
(.279)\end{array}$ & $\begin{array}{l}5.44^{* * * *} \\
(.390)\end{array}$ & $\begin{array}{l}6.87 * * * * \\
(.393)\end{array}$ & $\begin{array}{l}6.10^{* * * *} \\
(.451)\end{array}$ & $\begin{array}{l}6.90^{* * * *} \\
(.415)\end{array}$ \\
\hline $\begin{array}{l}\text { Emissions } \\
\text { Reduction }^{\mathrm{a}}\end{array}$ & $\begin{array}{l}.00908^{*} \\
(.00414)\end{array}$ & $\begin{array}{l}.00624+ \\
(.00351)\end{array}$ & $\begin{array}{l}.00716^{* *} \\
(.00275)\end{array}$ & $\begin{array}{l}.00731+ \\
(.00386)\end{array}$ & $\begin{array}{l}.00188 \\
(.00388)\end{array}$ & $\begin{array}{l}.00226 \\
(.00444)\end{array}$ & $\begin{array}{l}.00338 \\
(.00409)\end{array}$ \\
\hline Liberal $^{b}$ & $\begin{array}{l}.159 * \\
(.0735)\end{array}$ & $\begin{array}{l}.147^{*} \\
(.0625)\end{array}$ & $\begin{array}{l}.117^{*} \\
(.0490)\end{array}$ & $\begin{array}{l}.156^{*} \\
(.0867)\end{array}$ & $\begin{array}{l}.143^{*} \\
(.0691)\end{array}$ & $\begin{array}{l}.0961 \\
(.0791)\end{array}$ & $\begin{array}{l}.153^{*} \\
(.0729)\end{array}$ \\
\hline R-square & .04 & .03 & .05 & .03 & .02 & .007 & .02 \\
\hline $\mathrm{N}$ & 243 & 244 & 244 & 242 & 244 & 243 & 244 \\
\hline
\end{tabular}

Reduce Bill Condition

\begin{tabular}{|c|c|c|c|c|c|c|c|}
\hline & $\begin{array}{l}\text { Model } 6 \\
\text { Altruistic } \\
\text { b (s.e.) }\end{array}$ & $\begin{array}{l}\text { Model } 7 \\
\text { Nice } \\
\text { b (s.e.) }\end{array}$ & $\begin{array}{l}\text { Model } 8 \\
\text { Care } \\
\text { b (s.e.) }\end{array}$ & $\begin{array}{l}\text { Model } 9 \\
\text { Trust } \\
\text { b (s.e.) }\end{array}$ & $\begin{array}{l}\text { Model } 10 \\
\text { Neighbor } \\
\text { b (s.e.) }\end{array}$ & $\begin{array}{l}\text { Model } 11 \\
\text { Know } \\
\text { b (s.e.) }\end{array}$ & $\begin{array}{l}\text { Model } 12 \\
\text { Unselfish } \\
\text { b (s.e.) }\end{array}$ \\
\hline Intercept & $\begin{array}{l}7.97 * * * * \\
(.866)\end{array}$ & $\begin{array}{l}8.10 * * * * \\
(.724)\end{array}$ & $\begin{array}{l}8.13^{* * * *} \\
(.601)\end{array}$ & $\begin{array}{l}7.58 * * * * \\
(.880)\end{array}$ & $\begin{array}{l}8.81 * * * * \\
(.817)\end{array}$ & $\begin{array}{l}7.23 * * * * \\
(.877)\end{array}$ & $\begin{array}{l}6.35 * * * * \\
(.854)\end{array}$ \\
\hline $\begin{array}{l}\text { Bill } \\
\text { Reduction }^{c}\end{array}$ & $\begin{array}{l}-2.49 * * \\
(.956)\end{array}$ & $\begin{array}{l}-1.60 * \\
(.797)\end{array}$ & $\begin{array}{l}-1.61^{*} \\
(.662)\end{array}$ & $\begin{array}{l}-1.76+ \\
(.987)\end{array}$ & $\begin{array}{l}-2.04^{*} \\
(.900)\end{array}$ & $\begin{array}{l}-1.11 \\
(.966)\end{array}$ & $\begin{array}{l}.692 \\
(.941)\end{array}$ \\
\hline Liberal $^{\text {b }}$ & $\begin{array}{l}-.317+ \\
(.166)\end{array}$ & $\begin{array}{l}-.260+ \\
(.139)\end{array}$ & $\begin{array}{l}-.308^{* *} \\
(.116)\end{array}$ & $\begin{array}{l}-.221 \\
(.169)\end{array}$ & $\begin{array}{l}-.385^{*} \\
(.157)\end{array}$ & $\begin{array}{l}-.231 \\
(.169)\end{array}$ & $\begin{array}{l}.0865 \\
(.164)\end{array}$ \\
\hline $\begin{array}{l}\text { Liberal x } \\
\text { Bill } \\
\text { Reduction }\end{array}$ & $\begin{array}{l}.543 * * \\
(.184)\end{array}$ & $\begin{array}{l}.357^{*} \\
(.153)\end{array}$ & $\begin{array}{l}.378^{* *} \\
(.128)\end{array}$ & $\begin{array}{l}.331+ \\
(.187)\end{array}$ & $\begin{array}{l}.500 * * \\
(.173)\end{array}$ & $\begin{array}{l}.315+ \\
(.186)\end{array}$ & $\begin{array}{l}-.0773 \\
(.181)\end{array}$ \\
\hline $\begin{array}{l}\text { R-square } \\
\mathrm{N}\end{array}$ & $\begin{array}{l}.05 \\
251\end{array}$ & $\begin{array}{l}.02 \\
254\end{array}$ & $\begin{array}{l}.04 \\
254\end{array}$ & $\begin{array}{l}.02 \\
254\end{array}$ & $\begin{array}{l}.04 \\
254\end{array}$ & $\begin{array}{l}.02 \\
254\end{array}$ & $\begin{array}{l}.01 \\
254\end{array}$ \\
\hline $\begin{array}{l}{ }^{\mathrm{c}} \text { Bill Reduct } \\
\text { 'biberal: } 1= \\
+\mathrm{p}<.1 ;{ }^{*} \mathrm{p}<\end{array}$ & $\begin{array}{l}\text { n: } 0=\text { no bill } \\
\text { ery conserv } \\
5 ;{ }^{* *} p<.01\end{array}$ & $\begin{array}{l}\text { duction; } 1 \\
\text { se; } 7=\text { very } \\
\text { wo-tailed }\end{array}$ & $\begin{array}{l}\text { Il reduction } \\
\text { eral } \\
\text { ts) }\end{array}$ & & & & \\
\hline
\end{tabular}

